\title{
Azerbaycan İstiklaline Adanmış Bir Ömür: Abdulvahap Yurtsever
}

DOI: $10.26466 /$ opus.691118

\section{Ümit Akın *}

*Dr. Öğr. Üyesi, Bandırma Onyedi Eylül Üniversitesi İnsan ve Toplum Bilimleri Fakültesi Türk Dili ve Edebiyatı Bölümü E-Posta: $\underline{\text { umitakin@mu.edu.tr }}$

ORCID: 0000-0003-1669-5399

\section{Öz}

Azerbaycan kurtuluş hareketinin önde gelen fikir adamlarından olan Abdulvahap Yurtsever, ömrünü Azerbaycan'ın bağımsızlı̆̆ına adamış aydınlardan biridir. 27 Nisan 1920'de Azerbaycan'ın Sovyet Rus tahakkümü altına girmesinin hemen ardından Musavata bağhl olarak kurulan gizli teşkilat Mukavemet Komitesinin başkan yardımcılığını yürütmüş̧ür. Yurtsever, bu teşkilatın Bolşevik hükümetine karşı yürüttü̈̆̈̈ mücadeleden dolayı tutuklanmış, ÇEKA'nın zindanlarında işkenceye maruz kalmıştır. Bir süre sonra cezası tamamlanmışsa da Sovyet idaresi onu bu sefer on bir yıl hapse mahkûm etmiştir. Yaptığı planla kurtulmayı başaran Yurtsever; kader yoldaşı, dava arkadaşı Mehmet Emin Resulzade'nin yönlendirmesiyle zor da olsa Ağustos 1936'da Avrupa'da düzenlenen Müsavat Partisi Kongresine katılır. Siyasî mücadelesini Azerbaycan muhaceretinin diğer temsilcileri ile devam ettirebilmek için 1939'da Türkiye'ye gelir, hukuk okur. 1949'da Azerbaycan Kültür Derneğinin kurulmasında önemli rol oynar. Derneğin 1952'de çıkarttı̆̆ı Azerbaycan dergisinin başyazarlarından biri olur. Azerbaycan'ın ve işgal altındaki Türk memleketlerinin bağımsızlık sesini bu dergi aracıllğıyla dile getirir. Tarih, edebiyat, sanat, kültür, tiyatro gibi birçok alanda ilmî ve nazarî yazllar kaleme alan Yurtsever, Azerbaycan muhaceret temsilcilerinin yol göstericisi de olmuştur. Çalı̧̧mamız doküman araştırmasına dayanmakta olup Yurtsever'in hayatı, siyasî mücadelesi, edebî faaliyetlerini kapsamaktadır.

Anahtar Kelimeler: Azerbaycan, Abdulvahap Yurtsever, Rusya, istiklâl 


\title{
A Life Dedicated to Azerbaijan Independence: Abdulvahap Yurtsever
}

\begin{abstract}
Abdulwahap Yurtsever, one of the leading ideas men of the Azerbaijan liberation movement, is one of the intellectuals who devoted his life to the independence of Azerbaijan. On 27 April 1920, he was the vice-chairman of the secret Resistance Committee established under Musavat immediately after Azerbaijan came under Soviet Russian domination. Yurtsever was arrested for his struggle against the Bolshevik government and tortured in the dungeons of the Cheka. After some time his punishment was completed, but the administration sentenced him to eleven years in prison. Yurtsever, who managed to escape with his plan, participated in the Musavat Party congress held in Europe in August 1936, with the guidance of his friend, sidekick and master Mehmet Emin Rasulzade. In order to continue his political struggle with other representatives of the Azerbaijani emigration, he came to Turkey in 1939 and studied law. He played an important role in the establishment of the Azerbaijan Cultural Association in 1949. He was one of the editors of the Azerbaijan journal published by the association in 1952. The voice of the independence of Azerbaijan and the occupied Turkish countries cries out to the world through this journal. Yurtsever has written scientific and theoretical writings in many fields such as history, literature, art, culture, theatre, and has also been the guide of the representatives of the Azerbaijani emigration. Our work is based on document research and covers the life, political struggle and literary activities of Yurtsever.
\end{abstract}

Keywords: Azerbaijan, Abdulvahap Yurtsever, Russia, independence. 


\section{Giriş}

1917 ihtilaliyle Rusya'da hâkimiyeti ele geçiren Bolşevikler, hiç vakit geçirmeden Rus tahakkümü altındaki milletlerin istiklaliyle ilgili bir beyanname neşretmişlerdir. Müslümanlara hitaben yazılan bu beyanname 15 Kasım 1917 tarihli olup aşağıdaki maddeleri içermektedir:

1. Rusya milletleri müsavat ve hükümranlik haklarna malik olacaklardır.

2. Rusya milletleri kendi mukadderatlarma bizzat kendileri hâkim olup, Rusya'dan tamamiyla ayrı, müstakil devlet kurabileceklerdir.

3. Her nevi millî ve dinî imtiyaz ve tehditler kaldirnlacaktır.

4. Rusya arazisi dâhilinde kalan azınlk milletlerin ve etnik zümrelerin serbest inkişafları teminat altma almacaktır (Bala, 1967, s.16) .

Lenin ve Stalin imzası taşıyan bu beyanname 1918 'de Moskova'da İş̧̧i ve Köylü Hükümetinin Kanun ve Kararnameler Dergisi'nde "Rusya Milletlerinin Hakları Beyannamesi" ismiyle yayımlanır.

Milletlere sözde özgürlük hakkı tanıyan ve bunu tüm dünyaya göstermelik ilan eden Bolşevikler, millî iradeyi temsil hakkını kayıt altına aldıktan sonra bu işin böyle olmayacağını çok geçmeden göstermişlerdir. Stalin'in 1938'de yazdığ 1 "Marksizm ve Milliyet Meselesi"nde bu durum şöyle itiraf edilmektedir:

"Bir milletin, serbest bir surette ayrnlip kendine mahsus müstakil bir devlet kurmak hakkına malik olmakla, bu hakkn kullanılması zamanı birbirinden ayrı meselelerdir. Bunlar birbirine karıştırılmamalıdır. Milletlerin istiklâl hakkın kabul etmekle biz bu milletlerin Rusya'dan ayrulmalar lazım geldiğini kabul etmiş oluyoruz. Ben bir millet için kabul ettiğim istiklâl hakkını tahakkuk ettirmek mecburiyetinde değilim. Bir millet istiklâl hakknna malik olabilir; fakat bu haktan istifade etmeyebilir de. Bir komünist olmak itibariyle bu hak aleyhinde çalışmak hürriyetini her zaman için muhafaza ederim (Bala, s.18)."

Bir milletin ayrilıp kendi istiklâlini ilan edebilmesi için milletin iradesini kimlerin temsil edeceği konusunda parti sınıf görüşü devam edecektir. Yani millet adına yalnızca işçi sınıfı konuşabilecekti. Bu durum istiklâl isteyen halkın yeni bir millet, Sovyet milleti, yapılmak istenmesinden başka şey değildi. 
Yani vaat edilen istiklâl, sadece beyannamede bir yazı olarak kalmıştır. İstiklâl hakkı bir kenara fikrî özgürlüğe dahi müsamaha göstermeyen bir sistemle halkın yaşam hakkına çok şiddetli müdahalelerde bulunulmuştur.

Bolşeviklerin ihtilali sonucunda, Azerbaycan, Ermenistan ve Gürcistan ile birlikte Maverayı Kafkas Cumhuriyeti oluşmuştur. Bir süre sonra Gürcistan'ın Maverayı Kafkas Cumhuriyeti'nden çıkarak bağımsızlığını ilan etmesi üzerine seymde bulunan Azerbaycan milletvekilleri, Azerbaycan Milli Şurasını ilan etmiş, başkanlığına Müsavat Partisi lideri Mehmet Emin Resulzade'yi ${ }^{1}$ seçerek 28 Mayıs 1918'de Azerbaycan Halk Cumhuriyeti'ni ilan etmişlerdir (Bala, 1991, s.89). Fakat bu durum 23 ay sürmüş 27 Nisan 1920'de Rus Kızıl Ordusu Azerbaycan'ı işgal ederek büyük kırgın ve yağmalar yapmış, bağımsız Azerbaycan Halk Cumhuriyeti'ne son vermiştir. Rusların baskı ve zulümlerine boyun eğmeyen milli şuurlu gençlerin bir kısmı tutuklanmış, sürgüne gönderilmiş, ölümle cezalandırılmış, bir kısmı da başta Türkiye ve İran olmak üzere mücadelelerini vatanlarından uzakta sürdürmüşlerdir. Mehmet Emin Resulzade, Mirza Bala, Ahmet Caferoğlu, Hüseyin Baykara, Mustafa Hakkı Türkekul, Süleyman Tekiner gibi birçok şahsiyet bir yandan Azerbaycan'ın haklılığını gazete, dergi gibi basın yayın organları ve siyasi teşkilatlar yoluyla dünya kamuoyuna duyurmaya çalışırken diğer yandan Azerbaycan muhaceret edebiyatının önemli örneklerini oluşturmuşlardır. Abdulvahap Yurtsever de siyasi ve içtimai mücadelede yukarıda ismi zikredilen önemli kişiler arasında yerini almıştır.

\section{Abdulvahap Yurtsever'in Hayatı}

Abdulvahap Yurtsever'le ilgili yiğeni Mehmet Burç tarafından yazılan kısa nekrolojide o şöyle tanıtılmıştır:

\footnotetext{
${ }^{1}$ Mehmet Emin Resulzade (1884-1955): Azerbaycan Demokratik Cumhuriyeti'nin kurucusu, siyasetçi, Millî Azerbaycan hareketinin önderi, dava adamıdır. 31 Ocak 1884'te Abşeron'un Novhanı köyünde doğmuştur. ilk eğitimini Rus-Müslüman Mektebi'nde aldıktan sonra Bakü Teknik Mektebi'ne devam etmiştir. Himmet Partisi'nin 1904'te kurulmasında rol oynamıştır. 1905 Rus ihtilaliyle sağlanan serbestlikten faydalanarak birçok içtimaî-siyasî yazılar kaleme aldı. Iran'a giderek Milli kurtuluş hareketlerine katıldı. 1917 yılında dava arkadaşlarının ısrarıyla Müsavat Partisi'nin Başkanı oldu. 1917'de yaşanan Rus Devriminden sonra 28 Mayıs 1918'de bağımsız Azerbaycan Cumhuriyeti'ni kurmuş ve Başkanı olmuştur. 1920 Rus Kızıl Ordusunun istilasıyla bağımsız Azerbaycan'a son verilince mücadeleyi yürütmek için Türkiye'ye geldi. Burada birçok siyasî teşkilatlanma yaparak gazete, dergi, toplantı ve konferanslarla Azerbaycan'ın haklı mücadelesini dünya kamuoyuna anlatmaya çalıştı. Azerbaycan'ın bağımsızlığı uğruna hayatını adayan Resulzade, Türkçülük hareketinin önemli ismi olmuş, 6 Mart 1955'te Ankara'da vefat etmiştir. Bkz. Yagublu, N. (2015). Mehmet Emin Resulzade Ansiklopedisi, Ankara: Azerbaycan Kültür Derneği Yayınları.
} 
“Abdulvahap Bey, 1898'de Azerbaycan'ın merkezi Bakü'de dünyaya gelmiştir. Babası Hacı Zeynelabidin Bey, annesi Cevahir Hanım'dır. Babasının ilk evliliğinden Mehmet Yusuf ve İskender adında iki oğlu, ikinci evliliğinden de Abdulvahap, A $\breve{g} a$ Rahim ve Gaffar adında üç oğlu ile Fatma ve Zübeyde isminde de iki kızı vardır. (Burç, 1976, s.29)."

Abdulvahap Bey'in ilk eğitim hayatı, 1905 Meşrutiyetinin oluşturduğu sınırlı hürriyet ortamında başlar. Daha sonra 1911'de III. Aleksandr Lisesine gider. Eğitim hayatı oldukça başarılı olan Abdulvahap Bey, boş zamanlarında Arapça, Farsça ve Kuranı Kerim tefsirlerini öğrenir. Bu lisede Rusçayı da iyi bir şekilde öğrenir. 1916'da Muhammediye adlı öğrenci derneğiyle siyasi hayata atılır ve bu tarihten 1976'ya kadar Azerbaycan millî davasına hizmet eder. 27 Nisan 1920'de Azerbaycan'ın işgal edilmesi üzerine 28-29 Nisan 1920'de Müsavat Partisi Gençlik Kolu tarafından partinin lideri Mehmet Emin Resulzade' nin onayı alınarak gizli Mukavemet Teşkilatı kurulmuş, başkanlığa Mirza Bala², başkan yardımcılığına Abdulvahap Yurtsever, genel sekreterliğe de Cafer Cabbarlı ${ }^{3}$ getirilmiştir. Bu gizli teşkilatın görevi Bolşevik hükûmetine karşı mücadele göstermekti. Teşkilatın başkanı Mirza Bala, Rus ajanları tarafından takip edildiğinden bir süre saklanmış, daha sonra da

\footnotetext{
${ }^{2}$ Mirza Bala: 1898'de Bakü'de doğmuştur. Çocukluğunda büyük yokluk çeken Mirza Bala, ailenin geçim yükünü de üstlenir. Mücadeleci tavrı Resulzade'nin dikkatini çeker. Onun tavsiyesiyle Açık Söz, Basiret, Azerbaycan gazetelerine yazılar yazar. Resulzade'yle dava arkadaşlığı yapar. Gizli Müsavat Partisi teşkilatında görev alır. 1920'de Azerbaycan, Ruslar tarafından isgal edilince tutuklanır. Serbest kaldıktan sonra bir süre öğretmenlik yapar, ancak millî mücadelenin burada yürütülmeyeceğini anladıktan sonra önce Iran'a daha sonra Türkiye'ye gelmiş Azerbaycan Millî hareketi için özverili çalışmıştır. Resulzade'nin 1955'te ölümünün ardından Müsavat Halk Partisi başkanlığına ve Azerbaycan Millî Merkez Başkanlığına getirilir. Mirza Bala Nuhoğlu, A. Kut, M.M. Mehmetzade, M. B. Daşdemir ve Ali Kutluk imzalarıly fikirlerini Yeni Kafkasya, Azeri Türk, Odlu Yurt, Bildiriş, İstiklal, Kurtuluş, Azerbaycan, Cumhuriyet, Milliyet gibi gazete ve dergilerde dile getirmiştir. 8 Mart 1959'da kalp krizinden istanbul'da vefat etmiştir. Bkz. Şimşir, S. (1999). Azerbaycanlıların Türkiye'de Siyasî ve Kültürel Faaliyetleri 1920-1991, Ankara: Azerbaycan Kültür Derneği Yayınları, s.162.

${ }^{3}$ Cafer Cabbarlı: 1899'da Bakü'de doğmuştur. Hiciv ve lirik tarzda yazdığı ilk şiirleri Basiret, Mektep, Babayı Emir gibi yayın organlarında neşr edilir. Azerbaycan Halk Cumhuriyeti'nin kurulmasıyla sanat hayatında önemli ilerleme kaydetmiştir. Bu dönemde Türklerin önemli mücadelelerini anlattığı Edirne'nin Fethi ve Trablus Muharebesi piyeslerini yazar. Cafer Cabbarlı Azerbaycan'ın 1920'de Ruslar tarafindan isgal edilmesiyle başlarda Müsavat Partisi Gizli Mukavemet Teşkilatında görev alsa da Sovyetlerin Azerbaycan'a hâkim olmasıyla bu sona erer. Bir süre sonra Sovyet hâkimiyetindeki Azerbaycan'da, tiyatro okulunu ve Azerbaycan Devlet Üniversitesinde Şark Fakültesini bitirir. "Komünist" gazetesinde önemli hizmetlerde bulunur. 1932'de Sovyet sanatına büyük katkılarından dolayı "emektar sanat hadimi" unvanı verilir. 1934'te kalp krizinden Bakü'de vefat eder.
} 
İran'a geçerek mücadelesini muhaceretten yürütmeyi sürdürmüştür. Teşkilata ait gizli matbaanın bulunmasıyla komite üyeleri açığa çıkmış, Yurtsever 15 Haziran 1923'te tutuklanmış, 11 ay ÇEKA'nın çeşitli işkencelerine maruz kaldıktan sonra ${ }^{4}$ üç yıl Kuzey Kafkasya'ya sürgün cezasına gönderilmiştir (Çağatay, 1976, s.5). Sürgün cezasından sonra 1926'da yurda dönen Yurtsever, kısa süre sonra tekrar tutuklanır ve bu sefer 11 yıla mahkûm edilir. Önce Yaroslav'a sürülür, buradan Saratov'a nakledilir. Yurtsever, sürgün cezasındayken şartları lehine çevirerek sürgündeki profesörlerden İngilizce, Almanca, Fransızca, İspanyolca, İtalyanca öğrenmeye çalışır (Karaca, 1996, s.330). Abdulvahap Yurtsever, buradan sürgün arkadaşı Veli Mikayilzade'yle Türkistan'a geçme planları yapar, başarır da. Taşkent'te bir süre Kız Öğretmen Okulunda Almanca öğretmenliği yapar. Yurtsever' in bu okulda gördükleri ümidini daha da arttırmıştır. Komünist sistemin okulunda Türk tarihini, Türk kültürünü ve Türk birliğini anlatan Yurtsever, öğrencilerle yaşadığı bir olayı şöyle anlatır:

“Gene bir gün en yüksek sinıfta dersime devam ederken kız öğrencilerden bir ikisi parmak kaldırarak bir şeyler sormak istediler. Dersle ilgili sorular olacağını sanarak kendilerini dinlemeye hazırlandım. Fakat bu defa bambaşka bir konu ile karşılaşmış oldum. Kızlar benim nereli olduğumu soruyorlardı. Gayet müeddep bir tarzda tevcih ettikleri bu suale, "Azeri Türklerindenim" diye cevap verdim. O ana kadar sessiz sedasız oturan kızlar birdenbire ayağa firladılar:

\section{Ah, Azerî imişsiniz!}

Bunun üzerine yine müsaade alarak bir ricada bulundular:

Azerîceyi çok merak ediyoruz. Acaba, bizim Özbekçeye benzer mi, benzemez mi?

Kendilerine şu karşıllı̆̆ verdim:

Türk soyu ve Türk dili tarihten gelen bir bütündür. Dünyanm çeşitli uzak noktalarına yayıldıkları için lehçeleri bir parça değişmişstir. Fakat kelime kökleri değişmezdir. Lehçelerimize başkalık veren yabancı kelimelerdir. Bunları toptan atacak olursak, nerede bulunursak bulunalım, hepimiz birbirimizi anlarız. Hele aydinlar birbirini an-

\footnotetext{
${ }^{4}$ Yurtsever, gerek işkencede gerekse sürgündeyken yaşadıklarını 1949'da Türkiye'de kurulan Azerbaycan Kültür Derneğinin yayın organı Azerbaycan dergisinde "Azerbaycan İstiklal Savaşından Sahneler" başlığıyla tefrika halinde yayımlamıştır. Dönemin önemli olaylarının canlı şahidi olan, yaşayan bir kişi olarak ilk elden kaynak görevi gören ve oldukça önem arz eden bu yazılar tarafımızca toplanmış, kısa süre sonra kitap olarak yayımlanacaktır.
} 
lamakta hiçbir güçlük çekmezler. Ben Taşkent'e yeni geldim. Azerîve Anadolu lehçelerinden başka Tatarca ve Başkurtçaya da aşinayım. Fakat Özbekçe gazete ve kitapları daha yeni okumaya başladım. Buna rağmen her okuduğumu kolayca anliyorum ve konuşanlarn da hemen kavrlyorum. Kendim konuşurken tabiî Azerîce ve Tatarca tabirler de karıştırıyorum. Bunu herhalde siz de sezmişsiniz. Halis Özbekçe konuşabilmem için bir müddet zaman ister. O zamana kadar siz de kusurlarmm affedersiniz. Acaba, bütün bu söylediklerimi anlıyor musunuz?

Mükemmel anlıyoruz, diye hep bir ă̆ızdan haykırdılar. Fakat asıl istediğimiz Azerî konuşmasın dinlemektir. Acaba, anlar mıyız, anlamaz mıyız?

Bunu söyledikten sonra şöyle bir ricada bulundular:

Lütfen, bize bir iki ders ayırarak, Azerbaycan tarihini surf Azerî lehçesi ile anlatabilir misiniz?

Bu teklifi memnuniyetle kabul ettim ve içimde genç kızlarn bu makul isteğini hayranlikla alkışladım. Hemen Alman gramerini bir tarafa bırakarak Azerbaycan tarihini anlatmaya başladım. Konuşmamda bir tek yabancı kelime kullanmamaya azamî dikkat ettim. Bugünkü Azerbaycan topraklarına Türk göçlerinin başladığı tarihten tâ Rus istilâsına kadar Azerbaycan halkınn geçirdiği tarihî safhalar birer birer anlatmam birkaç dersi içine aldr. Fakat daha söze yeni başlayışımda, hepsi bir ă̆gzdan bana dönerek:

Siz Özbekçe konuşuyorsunuz, bu Azerîce değil. Çünkü anlamadığımız bir tek nokta kalmadr.

Ben Özbekçeyi yeni öğrenmeye başladığımı size evvelce söylemiştim. Konuşmamı Azerîce yapıyorum. Henüz Özbekçe konuşabilecek durumda değilim. Fakat yabancı sözcükleri kullanmaktan kaçındım ve sizlere sade Türkçe hitap ettim. İşte, bundan dolayıdır ki sözlerim kolayca anlaşılmış oluyor. Memleket dışına sı̆̆ınmaya hazırlanırken, meçhul bir istikbalin eşiğinde, belki de son millî vazifemi yaparak, genç Özbek kızlarına koyu komünist çeoresi içinde hiç çekinmeden şanlı Türklük tarihini hatırlatıyordum ve onlar da bu konuşmaları can kulağı ile dinliyorlardı. Sonra ne olacağımı bilmiyordum, fakat saçılan tohumlarm bir gün iyi semere vereceği muhakkaktı. İşte, bu neşe içinde millî vazifemize devam ediyorduk (Yurtsever, 1964, s.11-12)."

Daha sonra önce Aşkabad'a, oradan da İran'a geçen Yurtsever, 1936'da Mehmet Emin Resulzade'nin yönlendirmesiyle Varşova' daki Müsavat Partisi Kongresine katılmıştır. Burada önemli birçok karar alınmış, “Millî Azerbaycan Müsavat Halk Fırkasının Yeni Program Esasları" tespit edilmiştir. 
İkinci Dünya Savaşı'nın başlaması üzerine Türkiye'ye dönen Yurtsever, Basın-Yayın Genel Müdürlüğünde göreve başlar. Ankara' da Hukuk Fakültesini kazanarak iyi dereceyle bitirir. 1942'de Resulzade'nin davetiyle Berlin'e gider. Burada Alman resmi devlet adamlarıyla Azerbaycan hakkında müzakereler yürütülür (Sultanll, 2007, s.153). Görüşmelerde bir sonuç çıkmayınca Resulzade partinin faaliyet merkezi Bükreş'e döner, Abdulvahap Bey de tekrar Türkiye'ye gelir.

1947' de Müsavat Partisinin ve Azerbaycan Millî Merkezinin başkanı Mehmet Emin Resulzade'nin Ankara'ya gelmesiyle Azerbaycan siyasî muhacirleri arasında siyasî ve içtimaî birtakım faaliyetler yürütülür. Azerbaycan'ın haklı mücadelesi ve istiklalini, Azerbaycan tarihi, edebiyatı ve kültürünü Türkiye'ye anlatmak amaciyla 1 Şubat 1949'da Azerbaycan Kültür Derneği kurulur. Bu derneğin ilk faaliyetleri ilmî, edebî ve siyasî konferanslar vermek olur.

Azerbaycan Kültür Derneği, muhacerette bulunan aydınların aksisedası olmuştur. Abdulvahap Yurtsever de Derneğin 1952'de çıkartmaya başladığ "Azerbaycan Türk Kültür Dergisi"nin ilk sayısından itibaren Mehmet Emin Resulzade'yle derginin başyazarlarından olmuş, edebîs siyasî, nazarî yazılarıyla Azerbaycan millî davasını anlatmaya çalışmıştır.

Ömrünün 60 yıldan fazlasını Azerbaycan'ın millî davasına adayan Abdulvahap Bey, vasiyetinde dahi vârislerinden

“... Yalnı vârislerimden bütün hayatımı vakfettiğim Azerbaycan Kültür Derneğinin kutsal kurtuluş davalarnna yardımcı olmaların temenni ederim."

şeklindeki istekte bulunmuştur (Yurtsever, 1977, s.28).

Onunla tanışma bahtiyarlığına erişen ve 25 yıldır aynı amaçta yol arkadaşlığı yapan Ahmet Karaca, Abdulvahap Bey'in vefatının ardından kaleme aldığı yazısında onun son zamanlarını şöyle anlatır:

"Son aylarda sihhati iyice bozulmuştu. Ayaklarında meydana gelen şişten şikâyetçi idi. Evde bile bastonla yürüyorum diye dertlenirdi. Bu hastalığın bir seyri idi. Hastaneden çekinir bir durumu vardı. Şeker Bayramı'ndan önce idi, kendisini ziyaret ettim. Prof. Dr. Ahmet Sonal Bey'le görüştüğümü, Ankara Tip Fakültesi Hastanesine yatırlarak daha iyi tedavi edileceğini söyledim. Bayramdan sonra diyerek beni atlattı. Abdülvahap Yurtsever Bey, Ankara'nın meşhur bekârlarmdandı. Hiç evlenmemişti. Sordukları zaman hayatının en iyi zamanların Komünist zindanlarında, 
Sibirya sürgünlerinde geçirdiğini evlenmek hiç aklına gelmediğini belirtir, ben Azerbaycan Hürriyet ve İstiklâl Davast ile evliyim, derdi. Rahmete kavuşmadan iki gün önce idi. Telefonla hatırmı sordum. Sıhhatinin düzeldiğini, şişlerin ayaklarından çekildiğini, hastaneye yatmasına gerek olmadığını söyledi. Meğer bu son konuşmamızmış (Karaca, 1976, s.19)."

Azerbaycan Millî Merkezi Başkanı ve Azerbaycan Kültür Derneği Yönetim Kurulu üyelerinden olan mücadele adamı Abdulvahap Yurtsever, 7 Ekim 1976 Perşembe günü sabaha karşı Ankara Tunus Caddesindeki evinde, kalp yetmezliği nedeniyle vefat etmiştir. Ölüm haberi TRT'den duyuruldu. Gazetelerde onunla ilgili birçok taziye mesajı yayımlandı. Siyasî mecradan Başbakan, Başbakan yardımcıları, parti liderleri, bakan ve müsteşarlar tarafından taziyeler iletildi. 9 Ekim 1976 Cumartesi, Ankara Hacı Bayram Veli Camii'nde kılınan cenaze namazının ardından Karşıyaka Mezarlığı'na getirilmiş, mezarının başında hakkında konuşmalar yapılarak defnedilmiştir. Cenaze törenine Başbakan Yardımcısı ve MHP Genel Başkanı Alparslan Türkeş, birçok siyasi parti temsilcisi, Azerbaycan Kültür Derneği üyeleri ve çok sayıda vatandaş katılmıştır.

Yurtsever'in ölümünün ardından dava arkadaşlarından Yetkin Ural tarafından kaleme alınan yazıda Yurtsever şu cümlelerle nitelendirilir: "O denebilir ki sadece Azerbaycan için doğmuş, Azerbaycan için mücadele etmiş ve nihayet Azerbaycan için ölmüş̧ür (Ural, 1976, s.27)."

Vefatından önce kendisini ziyaret eden mücadele arkadaşlarından Ahet Ural Bey'e okuduğu Farsça beyitte “Ben bu gurbet ülkede ölür isem kabrimi kim kazacak, kefenimi kim biçecek? Benim tabutumu yüksek yerden geçirin, belki rüzgâr kokumu alı benim vatanıma götür[ür] (A. Ural, 1976, s.24)" diyerek dileğini belirtir ve nitekim de Karşıyaka Mezarlığı'nda yüksek bir yere defnedilir.

\section{Yurtsever'in Siyasî Mücadelesi}

Türk Dünyası için Türkiye/Anadolu her zaman anavatan olarak görülmüştür. Bundan dolayı da siyasî ve ekonomik menfaatler uğruna kendilerine zulüm edilen soydaşlarımızın bir kısmı vatanlarını terk etmek zorunda kalmış, mücadelesini Türkiye'de sürdürmüştür. Azerbaycanlı Türk aydınlar, 27 Nisan 1920'den sonra Bolşevik baskı ve şiddetinden kurtulmak için farklı ülkelere gitmişseler de mücadelenin merkezini Türkiye olarak görmüşlerdir. Bu mücadelede lider hiç şüphesiz bağımsız Azerbaycan Halk Cumhuriyeti'nin 
kurucusu Mehmet Emin Resulzade'dir. Abdulvahap Yurtsever, daha Bakü Lisesinde okurken Resulzade'nin "Dirilik" dergisinde yayımlanan yazı dizisinde milliyet mefkûresinin esaslarını ve Türklük ülküsüne dair yazılarını okumuş, "kendisine gryaben bağlandiğı Türklük mefkûresinin modern ilmi tarifini ve pratik tatbikini" ondan öğrenmiştir (Önal, 2019, s.282).

Abdulvahap Yurtsever, okul yıllarında kendine örnek aldığı ve yolundan gittiği Resulzade'yle daha sonra tanışacak ve aynı dava uğrunda birlikte mücadele edeceklerdir.

Yurtsever daha on sekiz yaşında iken "Muhammediye" adlı öğrenci derneğine girmiş, burada birtakım millî-içtimaî hareketlere katılmıştır. Aynı zamanda bu hareketin liderleri arasında yer almıştır. Bu hareket bir süre sonra büyüyecek Azerbaycan Millî Dava hareketine dönecektir. O, Millî Müsavat Halk Partisinin en alt kademelerinden başlamak suretiyle en üst kademelerinde de yöneticilik yapmıştır. Bu dernekte görev alan Mirza Bala, Piri Mürselzade $^{5}$, Cafer Cabbarlı, Veli Mikayilzade ${ }^{6}$, Hamit Ataman, Kerim Oder ${ }^{8}$

\footnotetext{
5 Piri Mürselzade: Bakü'nün Binakadı köyünde doğmuştur. Millî Azerbaycan hükümeti zamanında Müsavat Fırkasııın Bakü teşkilatı faal azasından biri olmuştur. 27 Nisan 1920'de Azerbaycan'ın işgaline karşı çıkmış, mücadeleci tavrı yüzünden Sovyet hükümetince ölüm cezasına çarptırılmıştır. Birkaç arkadaşıyla "Kum/Ölüm" adasına getirilmiştir. Bazı arkadaşlarında zaaf hisseden Piri Bey "Arkadaşlar mert olalım" diyerek vapurdan karaya ilk o atlamış, o anda göğsüne saplanan kurşunla oraya yığılmış ve son sözleri "Yaşasın istiklal" olmuştur. Bkz. Gültekin, "Istiklâl Şehitleri Mürselzade Piri Bey", Yeni Kafkasya 1923-1924, (Hzl. Yavuz Akpınar, Selçuk Türkyılmaz, Yılmaz Özkaya), istanbul: Teas Press, ss.238-239.

${ }^{6}$ Veli Mikayilzade, Azerbaycan Millî mücadelesinde bulunan önemli simalardandır. Abdulvahap Yurtsever'le Müsavat Gizli Mukavemet Teşkilatında görev yapmış, bir süre sonra Yurtsever'le tutuklanarak sürgüne gönderilmiştir. Yurtsever'in sürgün ve hapis arkadaşılır. Sürgün cezasından Yurtsever'le kaçmış, önce Taşkent'e daha sonra Iran'a gelmişlerdir. Daha fazla bilgi için bkz. Yurtsever, A.V. (1954). "Azerbaycan istiklâl Savaşından Sahneler", Azerbaycan. S. 28-29, s.11.

${ }^{7}$ Dr. Hamit Halil Ataman 2 Şubat 1900'de Kars'ta doğmuştur. Illköğrenimini Kars'ta almıştır. Ağabeyi Temimdar Bey'in Rus zulmüne karşı yürüttüğü çete mücadelesi nedeniyle aile fertlerinin tamamı malları ve mülkleri elinden alınarak Basarabya'ya sürgüne gönderilir. 1913'de Romanov Hanedanının tahta çıkmasıyla yayımlanan aftan yararlanarak Bakü'ye gelir. Liseyi burada bitirir. O sıralarda Bakü'de gelişen millî hareketlere katılır. Bir süre sonra Tıp Fakültesini burslu kazanır ve Almanya'ya eğitime gönderilir. 1934'te Türkiye'ye gelir ve burada hekimlik yapar. Ankara'ya yerleştikten sonra Samanpazarı semtinde açtığı muayenehane Kars ve Azerbaycanlı hemşerilerinin sık sık uğradığı yer olur. 1949'da Azerbaycan Kültür Derneği'nin kurucuları arasında yer alır. Derneğin uzun yıllar başkanlığııı yapar. Azerbaycan Milli Merkez Üyesi, Müsavat Partisi Divan Üyeliği ve Ankara Komitesi Başkanlığı görevlerde bulunur. Aynı zamanda Türk Dil Kurumunda da üyedir. Hamit Ataman 18 Mart 1979'da Ankara'da vefat eder. Daha fazla bilgi için bkz. Şimşir, S. (1999). Azerbaycanlıların Türkiye'de Siyasî ve Kültürel Faaliyetleri 1920-1991. Ankara: Azerbaycan Kültür Derneği Yayınları.

${ }^{8}$ Kerim Oder: 1899'da Bakü'de doğdu. ilk ve orta öğrenimini Bakü'de tamamladı. Daha sonra Müsavat Partisi Gençlik kollarında yer almıştır. Millî ve Demokratik Azerbaycan Cumhuriyeti döneminde Başbakanlık Özel Müdürlüğünde bulunarak politik hayatta tecrübe edindi. Milli Mücadelenin vatanında sürdürülemeyeceğini anlayan Kerim Oder, yurtdışına çıktı. Mehmet Emin Resulzade'nin yolundan devam eden Kerim
} 
gibi gençler, Müsavat Partisinin gençlik kollarını oluşturmuşlardır (Karaca, 1996, s.329).

1905 'te yaşanan Rus İhtilali'yle Rus tahakkümü altındaki Türkler ve Müslümanlar için önemli gelişmeler yaşanmıştır. Bu gelişmelerde önce kültürel birlik daha sonra siyasî istiklâl mücadelesi amaçlanmıştır. 1907'de Çarlık Rusya'nın serbest havası sona ermiş, daha şiddetli ve katı politikalarla birtakım baskılar başlatılmıştır. Bu baskılar sonucu bazı aydınlar Rusya dışına çıkmak zorunda kalmış, bazıları ise sürgüne gönderilmiştir. Mehmet Emin Resulzade de önce İran'a gitmiş, bir süre sonra da buradan Türkiye'ye geçmiştir. Mehmet Emin Resulzade, Çarlığın bir gün yıkılacağını bildiği için dava arkadaşlarına siyasî mücadeleyi gizli bir teşkilatla yürütmenin doğru olacağı tavsiyesinde bulunmuş, Müsavat Halk Partisinin doğmasına zemin hazırlamıştır. Partinin kurucularından olan Mehmet Ali Resuloğlu hatıralarında partinin kurulmasını şöyle anlatır:

1911 yllnnn sonbahar idi. Arkadaşlarn gizli toplantı ve müşavere yeri olan Kâzımzade Abbas Bey'in ${ }^{10}$ kurtasiye mağazasının arka odasinda Abbas Bey'le oturuyorduk. Arkadaşlarımızdan Taki Nakioğlu içeri girdi ve bize Gürcülerin, Ermenilerin ve Ruslarn siyasî partileri vardır. Bizim neden bir partimiz olmasin, biz de bir parti kuralım, dedi. Birkaç gün müzakere ve müşaveretten sonra Müsavat Partisini kurmaya karar verdik. Zaten Resulzade Emin Bey de o tarihlerde bulunduğu İstanbul'dan bizlere imâlarla siyasî bir teşekküle ihtiyaç olduğu hakkında yazılar yazmakta idi. Müsavat Partisinin programmda o günlerin siyasî havasma göre işçi ve köylü

\footnotetext{
Oder istiklâl ve hürriyet konusundaki mücadelesini muhacerette yürüttü. Müsavat Partisi, Azerbaycan Millî Merkezi, Azerbaycan Kültür Derneğinin genel başkanlığı yanında birçok harekette önemli görevlerde yer aldı. 12 Kasım 1981'de İstanbul'da vefat etti. Bkz. Şimşir, S. (1999). Azerbaycanlıların Türkiye'de Siyasî ve Kültürel Faaliyetleri 1920-1991. Ankara: Azerbaycan Kültür Derneği Yayınları.

${ }^{9}$ Mehmet Ali Resuloğlu: 7 Nisan 1882'de Bakü'de doğmuştur. Azerbaycan Milli Müsavat Halk Fırkasının kurucuları arasında yer alır. Mehmet Ali Resuloğlu, Resulzade'nin hem amcaoğlu hem de kayınbiraderidir. Azerbaycan'ın işgalinin ardından Azerbaycan millî mücadelesine katılmıştır. Íkinci Dünya Savaşının ardında Türkiye'ye gelerek CHP Genel merkezinde memur olarak görev yapmıştır.3 Şubat 1989'de İstanbul'da vefat etmiştir. Bkz. Karaca, A. (1982). "Mehmet Ali Resuloğlu'nu Anarken", Azerbaycan. S. 239. s.18-25.

${ }^{10}$ Abbas Kazımzade: 1882'de Bakü'de doğmuştur. Azerbaycan Milli Müsavat Halk Fırkasının kurucuları arasında yer alır. Mehmet Emin Resulzade’nin dava arkadaşıdır. Azerbaycan'ın işgalinin ardından istiklâl mücadelesi yürütür. Muhacerette Azerbaycan'ın haklı mücadelesini haykırmaya çalışmıştır. Azerbaycan Milî Merkezinin yönetim kadrosunda da görev almıştır. İstanbul Bayezıt'ta Azerbaycan Kütüphanesi ismiyle kitapevi açmıştır. 29 Temmuz 1947'de Ankara'da vefat etmiştir. Bkz. Dergi Heyeti (1953). "Rahmetli Kazımzade Abbas Illdeniz (Ölüm Yıl Dönümü Münasebetiyle" Azerbaycan, S.16. s.3.
} 
meselelerine çok önem verilmekte idi. Ayruca takriben şu mealde bir maddenin bulunduğunu da hatırlyyorum: İstiklâlini muhafaza etmiş Müslüman memleketlerinin (o zaman milliyet mefhumu pek revaçta değildi) istiklâllerinin korunmasina, istiklâllerini kaybetmiş Müslüman memleketlerinin de istiklâllerini kazanmaya yardımda bulunmak (Resuloğlu, 1966, s. 13).

Böylece Müsavat Halk Partisi 1911'de Bakü'de Mehmet Ali Resuloğlu, Abbas Kâzımzade ve Azerbaycan'ın zenginlerinden olan Taki Nakioğlu tarafından kuruldu. 1913'te Resulzade Bakü'ye dönmüş, parti üyelerinin isteğiyle partinin başına geçmiştir. Partinin programında birtakım değişiklikler yapan Resulzade, partiyi "Türk-İslam sentezini esas alan Türkçü bir anlayış" çerçevesinde şekillendirmiştir ${ }^{11}$ (Aküzüm, 1984, s.14). Abdulvahap Yurtsever de bu partide Divan üyeliği, genel başkan yardımclı̆̆ı gibi birçok görevde bulunmuştur (Karaca, s.330).

28 Mayıs 1918'de kurulan Azerbaycan Halk Cumhuriyeti'ne 27 Nisan 1920 'de Rus Kızıl Ordusu tarafından son verilmiş, aynı akşam Resulzade'den alınan direktifle Müsavatın gizli teşkilatı kurulmuştur. Bu teşkilatın kuruluşuyla ilgili olarak başkan yardımcısı olan Abdulvahap Yurtsever bu durumu şöyle açılamaktadır:

“... 27 Nisan akşamı Mirza Bala ile birlikte kendisini (M. E. Resulzade) evinde ziyaret ederek tasvibini almış ve arkadaşlardan Mehmet Sadık Kuluzade ve Mehmet Hasan Baharlı'yı merhum şair Cafer Cabbarlı'nun şehir kenarındaki ikametgâh̆nnda toplayarak yemin merasimiyle gizli parti Merkezi Umumisini kurmuştuk. Parti merkezi kurulduktan sonra vazife taksimine başlanmış ve komisyonlarm teşkiline geçilmişti. Emin Bey'in de iş'arn üzerine gizli teşkilatın başına oy birliği ile Mehmetzade Mirza Bala getirilmişti. Muavini sıfatıyla Bakü komitesi teşkilatı bana bırakılmıştı... Azerbaycan muhtelif bölgelerinde teşkilatı kurmakta hiçbir güçlük çekmemiştik. En ileri aydınlar, teşkilat işlerinde sınanmış iş̧̧iler ve açık fikirli köylüler akın akın bizi arayıp buluyorlardl. Hepsi mal ve can da dâhil her şeylerini vatan yolunda feda etmeye hazır bulunduklarm ifade ediyorlardı (Yurtsever, 1991, s.42)."

\footnotetext{
11 Parti 1917'de gizlenmeyi bırakmış, Azerbaycan'ın en büyük millî partisi halini almıştır. Ayrıca 1917'de Bakü'de gerçekleştirilen Kafkasya Müslümanları Kongresinde, Gence'de kurulan ve liderliğini Nesib Bey Yusufbeyli'nin yaptığı Türk Adem-i Merkeziyet Partisi'yle birleşmek için görüşmeler yapılmış ve nitekim başarılı olunmuştur. Partiler birleşerek Türk Âdem-i Merkeziyet Fırkası-Müsavat Partisi ismini almıştır. Bkz. Mehmetzade, M. B. (1991). Milli Azerbaycan Hareketi, Ankara: Azerbaycan Kültür Derneği Yayınları, s.50.
} 
Yurtsever'in yukarıda belirtilen yazısında gizli teşkilatın okullarda öğrenci örgütlenmelerinin oluşmasl, Azerbaycan istiklâli konusunda kamuoyu yaratılmaya çalışılması hatta Sovyetlerin polis teşkilatı G.P.U.'nun içine ajanlar yerleştirilmesi gibi birçok faaliyette bulunduğu belirtilir.

Liderliğini Mehmet Emin Resulzade'nin yaptığı Azerbaycan Millî Merkezi, İstanbul'da toplanan Azerbaycan Türklerinin kendi aralarında siyasî birlik sağlamak gayesiyle oluşturdukları siyasî bir kuruluştur. 1924-1931 yılları arasındaki faaliyet döneminde Abdulvahap Yurtsever, sürgün cezası nedeniyle bu merkezde görev alamamıştır. Ancak daha sonraki dönemlerde merkez başkanlığı gibi birçok görevde bulunmuştur. Merkez çalışma hedeflerini şöyle açıklamaktadır:

1. Merkez 28 Mayıs 1918'de kurulmuş ve dünya devletleri tarafindan istiklâli tanınmış iken 27 Nisan 1920'de Kızıl Rus ordularının istilasına uğramış bulunan Azerbaycan Halk Cumhuriyeti'nin egemenlik ve istiklâlini yeniden gerçekleştirmek uğrunda mücadele eder.

2. Aynı jeopolitik şartlar dâhilinde olup, aynı mukadderata ve aynı düşmana malik bulunan Kafkasyahı komşu milletlerin benzer teşekkülleri ile sıkı surette teşrik-i mesai eder.

3. Başta Rusya mahkûmu milletler olmak üzere kızl emperyalizmin esareti altında bulunan bütün milletlerin salahiyetli siyasî teşekkülleri ile müşterek komünizm tasallutuna ve Rus emperyalizmine karşı mücadele birliği yapar.

4. Dil ve Kültür birliği ile bağh olduğumuz mahkûm Türk illeri ile aramızdaki mevcut kardeşlik rabıtalarını her sahada kuvvetlendirmeye çalışır. Millî Merkez, sürgün hükümeti sıfatı ile Birleşmiş Milletler, Beynelmilel kurumlar, Bolşevik aleyhtar kuruluşlar ve davamiza muzahir dost devletler nezdinde Azerbaycan'ı temsil ve davayı müdafaa eder. Milli merkez, demokrasiye bağll, çok partili milli egemenlik ve istiklâlin kazanılmasından sonra siyasî faaliyetini memlekete nakleder, Azerbaycan'ın siyasî hayatında aktif olarak yerini alır (Şimşir, 1999, s.37-38).

Merkez faaliyetleri yürütürken özellikle Türkiye Cumhuriyeti'nin iç ve dış politikalarına zarar vermemeyi prensip kabul etmektedir.

Abdulvahap Yurtsever, sürgün cezasında sahte belgelerle İran'a geçtikten sonra Resulzade'nin davetiyle Polonya'nın Varşova kentinde Ağustos 
1936'da düzenlenen Müsavat Partisi Kongresine gelir. Kongrede “Millî Azerbaycan Müsavat Halk Fırkasının Yeni Program Esasları" belirlenmiştir. Bu kongrede alınan kararlarda onun da imzası yer alır. Özetle şu kararlar alınır:

1. Millî Azerbaycan Müsavat Halk Frrkasl, 1918'de Millî Azerbaycan Cumhuriyeti istiklâlinin ilannndaki teşebbüsü; bu teşebbüsün fikirden işe geçirilmesi yolundaki faaliyeti ve nihayet kısıl Rus istilâsına karşı millî mücadele işinde gösterdiği yol gösterenliği ile milliyetçi ve istiklâlci bütün Azerbaycanlıların biricik siyasî teşekkülü̈ür.

2. Müstakil Azerbaycan Cumhuriyeti, Rus istilâsindan kurtulacak, kayıtsız ve şartsız müstakil bir devlet halinde yaşayacaktır (Şimşir, s.71-72)."

İkinci Dünya Savaşı'nın başlamasıyla Polonya'nın Almanlar tarafından işgal edilmesi üzerine partinin merkezi önce İsviçre'ye, daha sonra Londra'ya bir süre sonra da Romanya'nın başkenti Bükreş'e nakledilir. AbdulvahapYurtsever, 1939'un sonlarına doğru Türkiye'ye gelir ve kendisi ve davası için önemli bir vazife alır. Basın Yayın Umum Müdürlüğünde çalışması kendi propagandasını yapması bakımından önemlidir. Çünkü Abdulvahap Bey; Rusça, Farsça, Arapça, Almancaya hâkimdir, Fransızca, İngilizce, Polonyaca gibi dilleri anlayarak da siyasî gelişmeleri takip edebiliyordur. O, Türk Radyosunda Farsça spikerliği ve yine aynı radyoda siyasî haber yorumculuğu da yapar (Çağatay, 1976, s.7).

Abdulvahap Bey, Resulzade'nin davetiyle 1942'de Berlin'e gitmiş, burada Azerbaycan'ın bağımsızlığıyla ilgili önemli meseleleri Alman siyasî temsilcilerle görüşmüşlerdir. Almanlarla yapılan görüşmelerde sonuç alınamamıştır. Çünkü Almanya, bağımsız Azerbaycan devletine sıcak bakmamaktadır. Ancak burada önemli bir meseleye daha el atılmış, Sovyet ordusunda savaşan ancak Almanlar tarafından esir alınan Azerbaycan Türk'ü askerlerin feci durumları da masaya yatırılmıştır. Ayrıca 6-9 Kasım 1943'te Berlin'de düzenlenen Azerbaycan kurultayında Azerbaycan'ın bağımsızlı̆̆ını tanımayan Almanya şiddetle tenkit edilmiştir (Şimşir, s.75). Resulzade Bükreş'e, Abdulvahap Yurtsever de Türkiye'ye dönmüştür. 
1947'de Resulzade'nin Türkiye'ye dönmesiyle Azerbaycan Türklerinde Azerbaycan millî hareketi adına bir heyecan başlar. Müsavat Partisi Başkanlık Divanının kararı ile Mehmet Altunbay ${ }^{12}$, Dr. Hamit Ataman ve Aziz Alpaut ${ }^{13}$ tarafından 1 Şubat 1949 'da Azerbaycan Kültür Derneği kurulur ve yayın organı olarak da 1952'de Azerbaycan Dergisi neşredilir. Bu derginin çıkış amaci "Şimdiye kadar sadece ilmî, edebî ve tarihî konferanslarm neşri ile iktifa eden derneğimiz, Ankara'da ve Taşra'da bulunan üyeleriyle kültürel bağlarmı daha fazla sağlamlaştırmak gayesiyle bu sefer bir derginin yayımlanmasına da lüzum duyulmuştur. Şimdilik ayda bir defa neşredilecek olan bu dergimiz vasıtasıyla derneğimizin üç seneyi aşan çalışmaları hakkında mufassal bilgi vereceğimiz gibi Anadolu Türklüğüne bunca manen ve maddeten yakm ve komşu bulunan Azerbaycan Türklüğünün tarihi, edebiyatı, sanatı, tiyatro hayatı hususlarnda yurttaşlara mümkün mertebe geniş bilgiler vermeye gayret edeceğiz" şeklinde açıklanmıştır (Azerbaycan, 1952, s.3).

Resulzade'nin sağlığında 35 sayı neşredilen derginin başyazarları Resulzade, Abdulvahap Yurtsever olmuştur. Her ne kadar dergi için yukarıdaki

\footnotetext{
12 1911'de Gence'de Ailesinden bazılarının kurşuna dizilmesi üzerine Bakü Petrol Üniversitesinin 1. sınıfından ayrılarak, Odessa Askeri Hava Okuluna girmiş, 1933'te mezun olmuş, pilotluk mesleğine başlamıștır. 1939'dan itibaren planlamaya başladığı kaçışı, bir müddet sonra Celal ve Hasan Zeynallı ile gerçekleştirir. ilk olarak Iran'a inerler. Burada bir yıl kadar hapis ve gözetim altında kaldıktan sonra 1941'de Bağdat'a gider. Buradan da bir müddet sonra Türkiye'ye geçer. Türkiye'ye gelen Mehmet Altunbay, 1943 yilında Genel Kurmay Başkanlığı tarafından Eskişehir Hava Okuluna gönderilir. Imtihanlarda başarılı olur ve pilotluk belgesi alır. 1945-1960 yılları arasında Türk Hava Yollarında pilot olarak çalısıır. 1949'da kurulan Azerbaycan Kültür Derneğinin kurucuları arasında yer alır. 1960-1963 yıllarında Azatlık radyosunun Azerbaycan şubesinde görev almıştır. Mehmet Altunbay, 28 Aralık 1987'de vefat eder. Altunbay, M. (1989). Hürriyete Uçan Türk Mehmet Altunbay'ın Hatıraları. Ankara: Azerbaycan Kültür Derneği Yayınları; Attar, A. ve Şimşir, S. (2003). Tarihten Günümüze Türkiye'de Yaşayan Azerbaycan Türkleri. Ankara: Berikan Yayınevi, s. 242. ${ }^{13}$ Aziz Alpaut, 1895 'de Dilican'da doğmuştur. Liseyi Tiflis'te okur ve Tıp Fakültesini kazanır. Ancak rahatsızlığı nedeniyle Estonya'nın Tartu şehrinde Hukuk Fakültesine kaydolur. Azerbaycan 28 Mayıs 1918'de bağımsızlığını kazandıktan sonra sorgu hâkimi olarak görev yapar. 27 Nisan 1920'de bağımsız Azerbaycan Cumhuriyeti'ne Kızıl Ordu tarafından son verilince hâkimliği bırakır, milli mücadeleye başlar. Bir müddet sonra yakalayarak ölüm cezasına çarptırılır. Bir süre sonra cezası müebbede çevrilir ve sürgüne Sibirya'ya gönderilir. Sahte belgelerle Aziz Alpaut hapishaneden kaçar. Önce Bakü'ye gelmiş, yakalanmamak için Iran'a geçmistsir. Buradan da Trabzon'a gelir. Fakat bir süre sonra Romanya'ya döner. 1927'de tekrar Türkiye'ye gelir. Deri yapım konusunda eğitimli olduğu için Atatürk'ün dikkatini çekmiştir. Atatürk'ün yardımıyla deri fabrikası kurma görevini üstüne alır. Fabrika iyi işler fakat Atatürk'ün rahatsızlığı için istanbul'a gitmesi işlerini sekteye uğratır ve fabrika 1937'de kapanır. Bu kez kimya eğitimi için Almanya'ya gider. Döndügünde kimya üzerine doktorasını tamamlar. 1949'da kurulan Azerbaycan Kültür Derneğinin kurucuları arasında yer alır. Tarım Bakanlığında müşavir olarak görev yapar ve 17 Haziran 1988'de vefat eder. Daha fazla bilgi için bkz. Attar, A. ve Şimşir, S. (2003). Tarihten Günümüze Türkiye'de Yaşayan Azerbaycan Türkleri. Ankara: Berikan Yayınevi, s. 256-258.
} 
amaç belirtilmişse de yazıların çoğu milli şuur ve inancın canlı tutulması üzerine kaleme alınmıştır. Yani dergi bir taraftan edebî yazılar ortaya koyarken diğer taraftan siyasî yazılarla okurlarını bilinçlendirmeyi ve onların milli şuurunu geliştirmeyi hedefler. Dergide; Azerbaycan tarihi, kültürü, edebiyatı, mimarisi, ekonomisi, istiklâl mücadelesi, Rusya esareti altındaki Türklerin meseleleri, 28 Mayıs Azerbaycan Halk Cumhuriyetinin kurulması, 7 Nisan istilası, klasik Azerbaycan edebiyatçıları, Sovyetlerin acımasız ve ölümcül işkenceleri ve halka yapılan baskı, komünist idarenin iç yüzü, Sovyetlerin dinsizleştirme politikası gibi büyük önem arz eden konular ayrıntılı olarak yer alır. Mesela, Sovyet tahakkümü altındaki Türklere karşı yürütülen acımasız ve katı siyaset, Abdulvahap Bey'in geniş perspektifli bakışıyla “Tesanüt İhtiyacı" başlıklı yazısında şöyle açıklanır:

"Her daim söylemiş olduğumuz gibi bizim davamız, sirfbize has ve bize münhasır bir dava olmayıp cihanşümul bir davadır. Hedef ve gayelerimiz hür dünyanın hedef ve gayeleri ile tamamen birleşmiş bulunmaktadır. Rus mahkûmu milletler kurtulursa bugün bütün dünyanm hürriyet ve emniyetini tehdit eden muazzam tehlike de ortadan kalkmış olur. Öyle ise bu büyük ve cihanşümul davayı birbiri ile kâfi derecede ilgisi ve bağhlı̆̆ı bulunmayan mahallîve mıntıkavî küçük davalar haline sokarak zayıf ve tesirsiz düşürmek hür ve bağımsız hiçbir milletin faydasına olamayacă̆g gibi Rus tahakkümünden kurtulma uğrunda savaşan sayısı pek çok kavimlerden dahi hiçbirisinin hakikî menfaatlerine uygun düşmez (Yurtsever, 1956, s.7)."

Abdulvahap Bey'in Sovyetlerin Ruslaştırma-Sovyetleştirme politikasını eleştirdiği yazısı dikkate değer bilgiler vermektedir. Yazıda Rusların bu siyaseti, ayrıntılı olarak ele alınmıştır. Önce alfabenin değiştirilmesinden başlamak suretiyle, millî tarih ve millî edebiyat yasaklanmış, eğitim Rusça olmuş, Rus tarihi, kültürü ve edebiyatı öğretilerek millî hissiyat kaldırılmaya çalışılmiştır:

"Soryet Rusya, Rus mahkûmu bütün Türk illerinin alfabesini, Latinceden Rusçaya çevirmiş, okullarında millî tarih ve edebiyatlarmı okumalarmı yasak etmiş, Rus dili, tarih ve edebiyatım Türk okullarmda okutulmasını en başta ders programına koyarak mecburî kılmış ve Stalin'in "tek ülke-tek millet" politikasını günü gününe izlemiştir. Komünist Rusya nereye ayak basmışsa oraya Rus nüfuzunu, Rus hâkimiyetini, Rus idare sistemini, Rus dili ve kültürünü götürmüştür. Sovyetler Birliği'ne dâhil bütün memleketler ve hatta sözde Müttefik Cumhuriyetler, siyasî, iktisadî, as- 
kerî ve kültürel her türlü bağımsızlı ve egemenlik haklarından mahrumdurlar. Tarlalarmı istedikleri gibi işleyemezler, fabrikalarm diledikleri gibi kuramazlar, kültür işlerini arzu ettikleri şekilde yürütemezler... (Yurtsever, 1965, s.7)."

Abdulvahap Bey'in böyle bir planın asla kabul edilmeyeceğini, Türklerin çalınan bağımsızlık ve milli egemenlik haklarının tekrar kazanılması için mücadeleyi her zaman sürdüreceğini belirtmesi, Sovyet Rusya'ya verilen bir ihtardir:

"Halk dünyanm her yerinde kendi öz milletinin ayrılmaz bir parçasıdır! Hiçbir halk, kendi milletinden ayrı ve kopmuş düşünülemez! Rus halkı Rus milletinin ayrılmaz bir parçasıdır. Türk halkı da Türk ulusunun tarih boyunca kaynaşmış bir uzvudur! Bu itibarla "Sozyet halkı" esir milletleri Ruslaştırmak ve yok etmek için düşünülmüş insanlık dışı şeytanî bir plandan başka bir şey değildir. Böyle bir planın gerçekleştirilmesine yüz milyonu çok aşkm Sơyet esir milletleri hiçbir zaman müsaade etmeyeceklerdir! Bunu iyi bilsinler (Yurtsever, 1974, s.6)!"

Başka bir yazısında Abdulvahap Bey, kendinden olmayan için her türlü yaşam hakkının yok edilmeye çalışıldığı Sovyet idaresinde, Sovyetlerin bu kez Müslüman halkı dinden uzaklaştırmaya çalıştı̆̆ı meselesini ele alır. Sovyetler bu işi plan ve programlı olarak yapmaya çalışır. Dini kitapları yasaklar, din adamlarını tehdit eder, sürgüne gönderir, öldürür. Medreseleri kapatır, Marksist kitaplar okutarak dinin gereksizliğini anlatır. Bu ve bunun gibi baskılarla halk dinden soğutulmaya çalışılmıştır. Abdulvahap Bey, yazıda bu yıldırma politikasının uzun yıllar sürdüğünü fakat başarılı olunamadığını anlatır:

"Tam kırk bir senedir Sozyet Komünist Partisi, dinî inançları ortadan kaldırmak için elindeki bütün siyasî, iktisadî, idar̂̂, inzibatî ve sözde ilim ve eğitim vasttalarnı kullanmaktadır. Başlangıçta Rusluğa has ve kabalık vahşetle cami ve mabetleri yıktırmak veya ahır, meyhane, ambar, yurt ve kuraathane olarak kullanmak, din adamlarm toptan öldürmek, hapse atmak ve sürmek, her nevi din kitaplarmm risale, dergi ve takvimlerinin neşrini yasak ve mevcudunu imha etmek, medreseleri kapatmak, "Allahsızlar Cemiyeti" ve ona bağhl resmî neşir organları vasıtasıyla ve kezâ bütün Sovyet basınının ve neşriyatını ă̆zıyla ve tekmil parti propaganda cihazının yardımıla Tanr'ya Peygamberlere, mukaddesata günü gününe sövmekle işe başladı. Bu kanlı mücadele uzun seneler boyunca devam etti; fakat hiçbir netice vermedi. Dininin ezildiğini gören halk daha derin imanla ona sarıldn (Yurtsever, 1958, s.23). 
Ahmet Karaca, Yurtsever'i "Sovyet sistemini dünyada en iyi bilen nadir insanlardan biridir" diyerek tanitır (Karaca, 1996, s.332). Çünkü o sistemin zulmünü bizzat yaşamıştır. Sovyet sistemi özgür düşünceye izin vermez, her türlü eleştiriye kapalıdır. "Bizden değilsen ya olacaksın ya öleceksin" fikriyle tavır sergiler. Abdulvahap Bey, 1918'de Lenin tarafından kurulan kanlı Çeka idaresiyle ilgili olarak bir makalesinde "Sorgusuz sualsiz on binlerce insanı ölüme gönderen bu hunharca idarenin yanında Ortaçă̆'ın Engizisyon müessesesi pek masum kalır. Yaptığı zulümler ve işkenceler dillere destandır" diyerek Sovyetlerin acımasızlığını göstermeye çalışır (Yurtsever, 1965, s.12).

Abdulvahap Bey, derginin yayımlanmaya başladığından ömrü vefa ettiği son zamana kadar yüzlerce yazı kaleme almış, Azerbaycan Millî davasıyla ilgili birçok basın toplantısı düzenlemiş, konferanslar vermiş, broşürler yayımlamış, dernek çatısı altında birçok etkinlik yapmıştır.

Abdulvahap Bey, Mehmet Emin Resulzade'nin 6 Mart 1955'te vefatından sonra Azerbaycan Millî Merkezi Başkanlığı görevini de üstlenir. ${ }^{14}$ Mehmet Emin Resulzade' nin çizdiği yoldan taviz vermeyen Abdulvahap Yurtsever, millî davayla ilgili birtakım dedikodulara “... Şüphesiz Azerbaycan Kurtuluş Davası bölünmez, parçalanmaz bir tek davadır. Esasları ve umdeleri sarih ve aşikârdır. Şahıslara ve gruplara bă̆h değildir. Onlarm fevkinde ve her nevi şahsî garazlara ve hasis menfaatlere alet ve vasita olmayacak kadar bütün bir millete mal olmuş kutsal bir davadır." diyerek cevap vermiştir (Önal, s.285).

Yurtsever, hayatını Azerbaycan İstiklâl ülküsüne vakfetmiş 43 yıllık dava arkadaşı Mirza Bala'nın 8 Mart 1959'da vefat etmesiyle Sovyetler Birliği Milletleri Kurtuluş Cemiyeti (Paris Bloku) ${ }^{15}$ kongrelerinde ve toplantılarında Azerbaycan temsilcisi olarak başkanlık yapmıştır. Abdulvahap Bey, bu toplantılarda Azerbaycan'ın ve Rus mahkûmiyeti altındaki bütün Türk ülkeleri-

\footnotetext{
${ }^{14}$ Resulzade'nin vefatından sonra Mirza Bala, Merkez Başkanlığına getirilmiştir. Ancak Mirza Bala, o tarihlerde Münih'te Sovyetler Birliği Tetkik Enstitüsünde çalışmakta olduğundan Türkiye'deki işler Abdulvahap Bey'in uhdesinde yürütülür. Abdulvahap Bey resmi olarak Bala'nın vefatından sonra Milli Merkez Başkanlığına gelir.

${ }^{15}$ Sovyet Rus emperyalizmine karşı kurulan biri Varşova'da diğeri Paris'te olan siyasî kuruluştur. Paris Promethe Kulubü; Azerbaycan, Gürcistan, Türkistan ve Ukrayna Milli Hükümet ve Kurtuluş Hareketleri temsilcilerinden oluşmaktaydı. Paris Bloku'nun ilk başkanı Gürcü Millî Hükümeti erkânından Gegiçkoridir. Onun ölümü üzerine Belorus Millî Merkezi Başkanı Abramçik daha sonra Ukrayna Millî Hükümeti erkânından Levitski başkanlığa seçildi. Bütün Türk temsilcileriyle beraber Azerbaycan da blok kuruluşunda ve faaliyetlerde yer aldı. Abdulvahap Yurtsever Paris Blokunun birçok kongresinde başkanlık yaptı. Çağatay, T. (1976). Abdulvahap Bey'in Ardından. Azerbaycan, S. 220.
} 
nin kurtuluş davalarını olgunlukla temsil etmiştir. Ayrıca 1950-1960'l1 yıllarda Sovyetler Birliği Araştırma Enstitüsü bünyesinde düzenlenen enstitü azaları ve kurtuluş̧̧u memleketler temsilcilerinin katıldığı kongrelerde de Azerbaycan'ı temsil etmiş Azerbaycan Millî davasını savunmuştur (Çağatay, s.8).

\section{Abdulvahap Yurtsever'in Edebî Faaliyetleri}

Abdulvahap Bey'in edebî faaliyetleri, daha çok dergi ve gazete sütunlarında yayımlanan ve konferanslarda, toplantilarda yapilan sunumlar olarak belirtilebilir. 1952'de Azerbaycan dergisinin başyazarlarından olduğu için fikirlerini, edebî araştırmalarını ve nazarî yazılarını hayatının sonuna kadar bu dergide yayımlar. Abdulvahap Bey'in dergideki yazılarına baktığımızda derginin ilk sayılarında edebî yazıların ağırlıkta olduğunu görmekteyiz. Ahmet Karaca, Abdulvahap Bey'in bu yazılarıyla ilgili olarak "Azerbaycan Milli Mücadele Tarihi yazanlarm onun 60 yll aşkın yazarlı dönemindeki kadar velut bir yazara rastlayacaklarına inanmiyorum. 60 yıl muntazam yazmış ve muntazam konuşmuş bir kimsedir." diyerek Yurtsever'in yazarlığını yüceltir (Karaca, s.333). Azerbaycan dergisinde yaptığımız araştırmalarda Yurtsever' in edebî özellikteki yazılarını şöyle sıralayabiliriz:

Abdulvahap Yurtsever, "Hurşid Banu (Netevan)”, Azerbaycan, 1.06.1952, S.3, s.6.

Abdulvahap Yurtsever, "Azerbaycan Dram Ediplerinden Cafer Cabbarlı" (Tefrika)

1.07.1952, S.4, s.7.

Abdulvahap Yurtsever, "Azerbaycan Dram Ediplerinden Cafer Cabbarlı", Azerbaycan, 1.08.1952, S.5, s.5.

Abdulvahap Yurtsever, "Azerbaycan Dram Ediplerinden Cafer Cabbarlı", Azerbaycan, 1.09.1952, S.6, s.6.

Abdulvahap Yurtsever, “Aşik Alesker (1821-1926)”, Azerbaycan, 1.10.1952, S.7, s.2.

Abdulvahap Yurtsever, "Abbas Sihhat (1874-1918)”, Azerbaycan, 1.01.1953, S.10, s.2.

Abdulvahap Yurtsever, "Tapmacalar (Bulmacalar)”, Azerbaycan, 1.01.1953, S.10, s.16.

Abdulvahap Yurtsever, “Kasim Bey Zakir (1774-1857)”, Azerbaycan, 1.02.1953, S.11, s.4.

Abdulvahap Yurtsever, “Kasım Bey Zakir (1774-1857)”, Azerbaycan, 1.03.1953, S.12, s.8.

Abdulvahap Yurtsever, "Kasim Bey Zakir (1774-1857)", Azerbaycan, 1.04.1953, S.13, s.5.

Abdulvahap Yurtsever, "19. Asır Azerbaycan'ındaki Modern ve Realist Edebi Cereyanlar", Azerbaycan, 01.05.1953, S.14, s.12.

Abdulvahap Yurtsever, "Mehseti Gencevi", Azerbaycan, 1.09.1953, S.18, s.12.

Abdulvahap Yurtsever, "Tiyatro Hayatımızda Hüseyin Araplı (1881-1919)", Azerbaycan, 1953, S.19, s.13. 
Abdulvahap Yurtsever, "Azerbaycan'in Sesi”, Azerbaycan, 1953, S.20-21, s.4.

Abdulvahap Yurtsever, “Şah İsmail ‘Hatai' (1486-1524)”, Azerbaycan, 1.03.1954, S.24, s.11.

Abdulvahap Yurtsever, "Şah İsmail ‘Hatai' (1486-1524)”, Azerbaycan, 1.04.1954, S.25, s.5.

Abdulvahap Yurtsever, “Kız Kalesi Hakkında Birkaç Söz”, Azerbaycan, 1962, S.127-128-

129 , s.16.

Abdulvahap Yurtsever, "Hasan Ali Yücel”, Azerbaycan, 1961, S.106-107-108, s.53.

Abdulvahap Yurtsever, "Mehmet Sadık ARAN (SAN'AN)", Azerbaycan, 1972, S.205, s.63.

Abdulvahap Yurtsever, “Ejder KURTULAN (1898-1971)”, Azerbaycan, 1972, S.205, s.70.

Abdulvahap Yurtsever, "Hüseyin Cemal Yanar'a”, Azerbaycan, 1974, S.210, s.71.

Abdulvahap Yurtsever, “Molla Penah Vakıf'la İlgili Memduh Şevket Esendal ile İlgili Bir

Hatıra", Azerbaycan, 1974, S.211, s.18.

Abdulvahap Yurtsever'in özellikle "Azerbaycan İstiklâl Savaşından Sahneler" başlıklı yaşadıklarını anlattı̆̆ı yazı dizisi de Azerbaycan tarihine 1şık tutacak ilmî ve tarihî değeri yüksek olan yazılardır.

Abdulvahap Bey'in yukarıda belirtilen edebî faaliyetlerinin yanında Azerbaycan Kültür Derneği tarafından düzenlenen toplantılarda yaptığı konuşmaların bazıları dernek tarafından kitap halinde yayımlanmıştır.

\section{Yurtsever, A. V. (1950). Mirza Fethali Ahundzade'nin Hayatı ve Eserleri, Ankara: Azerbaycan Kültür Derneği Yayınları.}

Yurtsever'in Ankara Kültür Derneğinin teşebbüsü ile 18 Mart 1950'de Ankara Dil ve Tarih-Coğrafya Fakültesinde verdiği konferans, Ankara Yeni Cezaevi Matbaasında kitap olarak yayımlanmıştır. Kitap; "Mirza Fethali'nin Yaşadığı Devir", "Mirza Fethali'nin Hal Tercümesi", "Filozof Mirza Şefi'nin Mirza Fethali Üzerindeki Tesiri", "Mirza Fethali'nin Eserleri” ve "Alfabe Meselesi" alt başliklarıyla okurlara sunulmuştur. Abdulvahap Yurtsever, bu önemli araştırmasında Azerbaycan'ın önemli mütefekkiri Ahundzade'yi ayrıntılı olarak ele almıştır. Onun hayatından, yaratıcılığına, yaşadığı siyasî-içtimaî çevreye dikkat çekerek Azerbaycan toplumunun geri kalmış taraflarını neden ve sonuçlarıyla ortaya koymuştur. "Alfabe Meselesi" başlığı, Ahundzade'nin üzerinde önemle durduğu ve ısrarla bir ıslahatın gerekli olduğunu söylediği konu olarak belirtilmiştir. Yazıda Ahundzade'nin söylemlerine atıfta bulunan Yurtsever, araştırmacılara çok önemli bilgiler verir. 
Yurtsever, A. V. (1950). Azerbaycan Dram Edebiyatı, Ankara: Azerbaycan Kültür Derneği Yayınlarn.

Abdulvahap Bey'in Azerbaycan Kültür Derneği tarafından düzenlenen 26 Kasım 1950'de Ankara Halkevinde verdiği konferans, Azerbaycan Dram Edebiyatı ismiyle Bayur Matbaasında kitap olarak basılmıştır. Abdulvahap Bey, bu konferansta Azerbaycan tiyatrosunun gelişimini ayrıntılı olarak değerlendirmiş, bunu yaparken de dönemin önemli olaylarından bağımsız kalmamıştır. "Mirza Fethali Devrindeki Tiyatro Hayatımız" kısımlı alt başlıkta Azerbaycan Dram edebiyatının kurucusunun Ahundzade olduğunu, onun tiyatrolarının birçok ülkede birçok dilde oynandığını, Azerbaycan tiyatrosunun onunla Avrupa'ya açıldığını belirtir. "Devrin Karakteristik Vasıfları" isimli alt başlıkta Abdulvahap Bey, emperyalist Rusya'nın Kafkasya ve Azerbaycan'ı sömürme nedenlerini ele alır. "Necef Bey Vezirli'nin Hayatı ve Eserleri" alt başlığında Azerbaycan milli tiyatrosunun kurulması ve gelişmesinde Necef Bey'in çok önemli olduğu anlatılır. Necef Bey'in bütün eserleri verilerek tahlil edilir. "Celil Mehmetkuluzade'nin Hayatı ve Eserleri" kısmında Azerbaycan edebiyatında onun bir çığır açtı̆̆ından bahsedilir. Celil Mehmetkuluzade'nin 1906'da çıkarttığı "Molla Nasrettin" ve edebî faaliyetine başladığ1 küçük hikâyeler de ele alınır. Özellikle onun "Ölüler" komedisi ile "Anamın Kitabı" Abdulvahap Bey tarafından ayrıntılı tahlil edilir. "Abdurrahim Hakverdili'nin Hayatı ve Eserleri" ve "Süleyman Sani Ahuntzade'nin Hayatı ve Eserleri" kısımlarında da ediplerle ilgili kısa; fakat toplu bir bilgi sunulmuştur.

\section{Yurtsever, A. V. (1951). Sâbir'in Azerbaycan Edebiyatındaki Yeri, Ankara: Azerbaycan Kültür Derneği Yayınlart.}

Abdulvahap Bey'in bu eseri Azerbaycan Kültür Derneği tarafından 26 Nisan 1951'de Ankara Halkevinde düzenlenen konferansı içermekte olup Doğuş Matbaası tarafından neşr edilmiştir. Kitaptan anlaşıldığı üzere Abdulvahap Bey, Sâbir'le ilgili geniş ve önemli araştırma yapmıştır. "Sâbir'in Azerbaycan Edebiyatındaki Yeri" alt başlığı aynı zamanda kitabın da ismi olup Sâbir'in yaşadığı devri detaylıca ele almaktadır. "Sâbir'in Hal Tercümesi" kısmında Abdulvahap Bey, Sâbir'le ilgili hal tercümesi kaleme alan Şair Abbas Sıhhat'tan faydalanır. Sâbir'in eğitiminden, yazdığı ilk şiirlerinden, şiirlerinin hangi neşr organlarında yayımlandığından Sâbir' in son zamanlarında Abbas 
Sihhat'a yazdığı mektuplardan bahsolunur. "Sâbir'in Siyasi Görüşleri" k1sımlı alt başlıkta ise Abdulvahap Bey, Sâbir'in şiirlerinden onun siyasî görüşünü tahlil eder ve onunla ilgili şu sonuca varır:

"Sâbir, Türkçüdür. Sâbir, hakikî bir Müslüman'dır. Sâbir, halkçıdır. Sâbir, hürriyet aşığıdır. Sâbir, Batı kültürünün hayranıdır. Sâbir, Rusçuluğa ve Rus tahakkümüne düşmandır. Işste Sâbir'in gerçek vasıfları bunlardan ibarettir. Sovyet-Bolşevik yazarlarımın Sâbir'i tahrif ederek başka şekilde göstermeleri, büyük şairimizin yüksek ve aziz hatırasina ihanet ve hakaretten başka bir mânâ ifade edemez (Yurtsever, 1951, s.58)."

Bu kısımda Abdülvahap Bey, Sâbir'in Türkiye'de irtica hareketi bastırıldiktan sonra tahtından olan Sultan Abdulhamid'in Muhammed Ali Şah ile hasbihalini ele aldığ "Benimki Bele Düştü" başlıklı şiirini de verir. "Sâbir'in Sosyal Görüşleri" alt başlıklı yazıda Sâbir' in Azerbaycan sosyal hayatında yapılmasını gerekli gördüğ̈̈ reformlar açıklanır. Azerbaycan'ın gelişmesi için köylünün hür ve serbest hayata kavuşması gerektiğinden bahsedilir. "Sâbir'in Sanat Hakkındaki Görüşleri" başlığı da Sâbir'in sanatını açılar. Sâbir'e göre sanat halk içindir, sanat hayat içindir. Abdulvahap Bey, Sâbir'in eserlerini bu görüşle kaleme aldığını söyler. "Sâbir'in Yaratıcılığının Bazı Özellikleri" kısmında Sâbir' in edebî gücünün ipuçları açıklanır. Bu kısımda Fuat Köprülü'nün Sâbir'le ilgili yazısına da atıf yapılır.

\section{Yurtsever, A. V. (1952). Azerbaycan Edebiyatında Vedadî ve Vakıf'in Yaratı- cılı̆̆ı, Ankara: Azerbaycan Kültür Derneği Yayınları.}

Azerbaycan Kültür Derneğinin Ankara Halkevinde 22 Mayıs 1952'de tertip ettiği konferans, kitap olarak Ankara Yeni Cezaevi Matbaası tarafından basılır. Abdulvahap Yurtsever'in bu eseri aynı dönem içinde yaşayan, farklı bakış açlarıyla eserler veren iki usta kalem sahibini ele alır. Sanatçlar değerlendirilirken yaşadığı dönemin siyasî, içtimaî ve edebî olayları göz önünde bulundurulur. Vedadî ve Vakıf, eserleri üzerinden açklanırken mukayeseli tahlil de yapilır.

\section{Sonuç}

Azerbaycan Millî Kurtuluş Hareketinin önemli ideologlarından olan Abdulvahap Yurtsever, hayatını Azerbaycan'ın bağımsızlığına adamıştır. Azerbaycan'ın yeniden istiklâli kazanması uğrunda birçok mücadele yürütmüştür. 
Rus emperyalizmine karşı amansız mücadele yürüten Yurtsever, her türlü sömürüye karşı çıkmış; her zaman hürriyetten ve gerçek demokrasiden yana bir tavır sergilemiştir. Sovyetlerin Çeka hapishanelerinde insanlık dışı muamelelere maruz kalması ve Çeka tarafından soydaşlarına yapılan zulümleri görmüş olması onun ülküsünü daima canlı tutmuştur.

Sovyet Rus tahakkümü altında yaşayan Türk ve Müslümanların gördüğü baskı, zulüm, işkenceleri de anlatmaktan çekinmez. O, Azerbaycan Halk Cumhuriyeti'nin kurucusu Mehmet Emin Resulzade'nin yolundan gitmiş, ilmini ve mücadelesini Resulzade' nin ülküsü etrafında şekillendirmiştir. Azerbaycan Milli Merkez Başkanı, Azerbaycan Kültür Derneği Yöneticisi, Azerbaycan dergisinin başyazarı olarak görev yapmış ve her platformda Azerbaycan'ın bağımsızlığını ve haklı mücadelesini anlatmaya çalışmıştır. O, Azerbaycan'ın tarihi, edebiyatı, tiyatrosunu ele alırken Azerbaycan milli davasını da vurgular. Onun ideali; başta Azerbaycan olmak üzere tüm Türk ülkelerinin bağımsızlığı üzerine kuruludur. 


\section{EXTENDED ABSTRACT}

\section{A Life Dedicated to Azerbaijan Independence: Abdulvahap Yurtsever \\ * \\ Ümit Akın \\ Bandırmöa Onyedi Eylül University}

The Bolsheviks, who took over the sovereignty of Russia with the 1917 revolution, quickly introduced a declaration on the independence of the nations under Russian domination. The Bolsheviks, who gave so-called nations the right to freedom and declared it as a spectacle to the whole world, soon showed that this would not be the case after registering the right to represent the national will. In order for a nation to secede and declare its own independence, the party class view on who will represent the will of the nation will continue. So only the working class could speak for the nation. This was nothing but the desire of the people who wanted independence to be made a new nation -the Soviet nation. In other words, the promised independence remained only as an article in the declaration. With a system that does not tolerate even intellectual freedom aside from the right to independence, very severe interventions have been made to the right to life of the people.

As a result of the above-mentioned revolution of the Bolsheviks, the Transcaucasian Republic was formed along with Azerbaijan, Armenia, and Georgia. After a while, Georgia declared independence from the Transcaucasian Republic, Azerbaijan MPs in the Assembly, declared to the National Council of Azerbaijan, chose Musavat Party leader Mehmet Emin Resulzade as President on 28 May 1918 Azerbaijan Democratic Republic (Bala, 1991, p.89) but this situation lasted 23 months and on 27 April 1920, the Russian Red Army invaded Azerbaijan and made great resentment and looting and ended the independent People's Republic of Azerbaijan. Some of the young people with national consciousness who did not submit to the oppression and persecution of the Russians were arrested, exiled, sentenced to death, and some of them continued their struggle away from their homeland, especially in Turkey and Iran. Abdulvahap Yurtsever has also taken his place among the important persons in the political and social struggle. 
Abdulvahap's first educational life begins in the environment of limited freedom created by the Constitution of 1905. Later, in 1911 He went to III. Aleksandr high school. Aldulvahap, who is very successful in his educational life, learns Arabic, Persian, and the Qur'ân Karîm Tafsir in his spare time. He also learned Russian well in this high school. In 1916, he started political life with the student association named Muhammadiyya and served the national cause of Azerbaijan from this date until 1976.

The occupation of Azerbaijan on 27 April 1920, on 28-29 April 1920 the secret Resistance organization was established with receiving approval of party leader Mehmet Emin Resulzade by Musavat Party youth section and Mirza Bala was inducted as President, Abdulvahap Yurtsever was inducted as Vice President. The mission of this secret agency was to demonstrate a struggle against the Bolshevik government. Yurtsever was arrested on 15 June 1923 due to the actions of the organization and sent to the North Caucasus for three years after being subjected to various tortures of the Cheka for 11 months. Yurtsever returned to the country in 1926 after the sentence of exile, was arrested again soon after and sentenced to 11 years. First, he was exiled to Yaroslav, from here he was transferred to Saratov. Abdulvahap Yurtsever planned to move to Turkistan with his exiled friend, Veli Mikayilzade. He taught German at a Girls' teacher's school in Tashkent for a while. What Yurtsever saw in this school further increased his hope. He described Turkish history, Turkish culture and Turkish unity in the school of the communist system. Later, he moved to Ashgabad and then to Iran, and in 1936 he attended the Musavat Party Congress in Warsaw under the direction of Mehmet Emin Rasulzade. Many important decisions have been taken here and "new program principles of National Azerbaijan Musavat People's Party" have been determined. Returning to Turkey after the start of the Second World War, Yurtsever came into office at the General Directorate of press and publications. He graduated from the Faculty of Law in Ankara with a good degree. In 1942, with the invitation of Rasulzade, he went to Berlin. Here, negotiations about Azerbaijan are conducted with German official statesmen (Sultanli, 2007, p.153). When the meetings failed, Rasulzade returned to Bucharest, the center of the party's activities, and Abdulvahap returned to Turkey.

In 1947, with the arrival of Mehmet Emin Rasulzade, the head of the Musavat Party and the Azerbaijan National Center in Ankara, some political and 
social activities were carried out among the Azerbaijani political emigrants. Azerbaijan Cultural Association was established on February 1, 1949, with the aim of explaining the right struggle and independence of Azerbaijan, history, literature and culture of Azerbaijan to Turkey. The first activities of this association were to give scientific, literary and political conferences.

Azerbaijan Cultural Association has been the echo of the emigrant intellectuals. Abdulvahap Yurtsever was the lead writer of the magazine with Mehmet Emin Rasulzade since the first issue of the "Azerbaijan Turkish Culture Magazine", which the Association started to publish in 1952, and tried to explain the national case of Azerbaijan with his literary and political writings.

The head of the National Center of Azerbaijan and one of the members of the Board of Directors of the Azerbaijan Cultural Association, struggler Abdulvahap Yurtsever, died of heart failure at his home Thursday, October 7, 1976, on Tunis Street in Ankara.

Abdulvahap Yurtsever, one of the important ideologues of the Azerbaijan National Liberation Movement, dedicated his life to the independence of Azerbaijan. He has fought many battles for the re-independence of Azerbaijan. Yurtsever, who waged a relentless struggle against Russian imperialism, has opposed all forms of exploitation and has always been in favor of freedom and true democracy. The fact that the Soviets were subjected to inhumane treatment in Cheka prisons has always kept his ideal alive. He did not hesitate to describe the oppression, persecution and torture experienced by Turks and Muslims living under Soviet Russian domination. He followed the path of Mehmet Emin Rasulzade, the founder of the People's Republic of Azerbaijan, and shaped his knowledge and struggle around the ideal of Rasulzade. He served as chairman of Azerbaijan National Center, Director of Azerbaijan Cultural Association, editor-in-chief of Azerbaijan magazine and tried to explain Azerbaijan's independence and right struggle on every platform. He also emphasized the Azerbaijani National Case when addressing the history, literature, and theatre of Azerbaijan. His idea was based on the independence of all Turkish countries, especially Azerbaijan.

\section{Kaynakça / References}

Aküzüm, F. (1984). Azerbaycan istiklâlinin tarihi gelişimi ve Resulzade. Azerbaycan, 248. 
Altunbay, M. (1989). Hürriyete uçan Türk Mehmet Altunbay'ın hatıraları. Ankara: Azerbaycan Kültür Derneği Yayınları.

Attar, A. ve Şimşir, S. (2003). Tarihten günümüze Türkiye'de yaşayan Azerbaycan Türkleri. Ankara: Berikan Yayınevi, 242.

Azerbaycan Kültür Derneği Yönetim Kurulu (1952). Yayına başlarken. Azerbaycan. 1, 4. Azerbaycan Dergi Heyeti. (1953). Rahmetli Kazımzade Abbas İldeniz:Ölüm yıl dönümü münasebetiyle. Azerbaycan, 16, 3-4.

Bala, M. (1967). Bolşeviklerin vadettiği istiklâl. Azerbaycan, 178-180, 16-18.

BURÇ, M. (1976). Amcazadem Vahap Bey. Azerbaycan. 220, 29

Çağatay, T. (1976). Abdulvahap Yurtsever'in ardından. Azerbaycan, 220, 4-8.

Gültekin, (2018). İstiklâl şehitleri Mürselzade Piri Bey. (Hzl. Y. Akpınar, S. Türkyılmaz, Y. Özkaya), Yeni Kafkasya 1923-1924, İstanbul: Teas Press.

Karaca, A. (1996). Muhaceretin fikir muallimi Abdulvahap Yurtsever. Türk Dünyası Aydınları Sempozyumu Bildirileri, Ankara: Türk Dünyası Araştırmaları Merkezi Yayınları, 329-333.

Karaca, A. (1976). Abdulvahap Yurtsever hocamı. Azerbaycan. 220, 18-19.

Mehmetzade, M. B. (1991). Milli Azerbaycan hareketi. Ankara: Azerbaycan Kültür Derneği Yayınları.

Önal, S. (2019). Azerbaycan Cumhuriyetinin 100. yılında mücadele adamı Abdulvahap Yurtsever. Yeni Türkiye, Ankara: Yeni Türkiye Stratejik Araştırma Merkezi.

Resuloğlu, M. A. (1966). Müsavat Partisinin kuruluşu. Azerbaycan, 167, 37-41.

Sultanli, V. (2007). Azerbaycan Muhaceret edebiyatı.(Çev. E. Uzun) İstanbul: Avrupa Yakası Yayınları.

Şimşir, S. (1999). Azerbaycanllarn Türkiye'de siyasî ve kültürel faaliyetleri 1920-1991, Ankara: Azerbaycan Kültür Derneği Yayınları.

Ural, Y. (1976). Bir kahraman daha göçtü. Azerbaycan. 220, 27-28.

Ural, A. (1976). A. Vahap Yurtsever. Azerbaycan, 220, 24.

Yakuplu, N. (2015). Mehmet Emin Resulzade ansiklopedisi. Ankara: Azerbaycan Kültür Derneği Yayınları.

Yurtsever, A. V. (1950). Mirza Fethali Ahundzade'nin hayatı ve eserleri. Ankara: Azerbaycan Kültür Derneği Yayınları.

Yurtsever, A. V. (1950). Azerbaycan dram edebiyatı. Ankara: Azerbaycan Kültür Derneği Yayınları.

Yurtsever, A. V. (1951). Sâbir'in Azerbaycan edebiyatındaki yeri. Ankara: Azerbaycan Kültür Derneği Yayınları.

Yurtsever, A. V. (1952). Azerbaycan Edebiyatında vedadî ve vakıf'ın yaratıcilı̆̆ı. Ankara: Azerbaycan Kültür Derneği Yayınları. 
Yurtsever, A.V. (1952). Hurşid Banu (Netevan). Azerbaycan, 3, 9-10.

Yurtsever, A.V. (1952). Hurşid Banu (Netevan). Azerbaycan, 3, 6-7.

Yurtsever, A.V. (1952). Azerbaycan Dram ediplerinden Cafer Cabbarlı (Tefrika). Azerbaycan, 4, 7-8.

Yurtsever, A.V. (1952). Azerbaycan dram ediplerinden Cafer Cabbarlı. Azerbaycan, 5, 58.

Yurtsever, A.V. (1952). Azerbaycan dram ediplerinden Cafer Cabbarli. Azerbaycan, 6, 68.

Yurtsever, A.V. (1952). Aşik Alesker (1821-1926). Azerbaycan, 7, 2-3.

Yurtsever, A.V. (1952). Tiyatro hayatımızda Hüseyin Araplı (1881-1919)". Azerbaycan, 19, 13-16.

Yurtsever, A.V. (1953). Abbas Sihhat (1874-1918). Azerbaycan, 10, $2-4$.

Yurtsever, A.V. (1953). Tapmacalar (Bulmacalar). Azerbaycan, 10, 16.

Yurtsever, A.V. (1953). Kasim Bey Zakir (1774-1857). Azerbaycan, 11, 4-6.

Yurtsever, A.V. (1953). Kasim Bey Zakir (1774-1857). Azerbaycan, 12, 8-9.

Yurtsever, A.V. (1953). Kasim Bey Zakir (1774-1857). Azerbaycan, 13, 5-10.

Yurtsever, A.V. (1953). 19. Asır Azerbaycan'ındaki modern ve realist edebi cereyanlar. Azerbaycan, 14, 12-17.

Yurtsever, A.V. (1953). Mehseti Gencevi. Azerbaycan, 18, 12-15.

Yurtsever, A.V. (1953). Azerbaycan'ın sesi. Azerbaycan, 20 -21, 4.

Yurtsever, A.V. (1954). Şah İsmail 'Hatai' (1486-1524).Azerbaycan, 24, 11-14.

Yurtsever, A.V. (1954). Şah İsmail 'Hatai' (1486-1524). Azerbaycan, 25, 5-8.

Yurtsever, A.V. (1954). Azerbaycan İstiklâl Savaşından sahneler. Azerbaycan, 28-29, 11.

Yurtsever, A. V. (1956). Tesanüt İhtiyac1. Azerbaycan, 54-55, 7-10.

Yurtsever, A. V. (1958). Sovyetlerin Din Düşmanlığı. Azerbaycan, 78-79, $23-28$.

Yurtsever, A.V. (1961). Hasan Ali Yücel. Azerbaycan, 106-107-108, 3.

Yurtsever, A.V. (1962). Kız Kalesi Hakkında Birkaç Söz. Azerbaycan, 127-128-129, 16-17.

Yurtsever, A. V. (1965). Komünizmle Savaş. Azerbaycan, 160-161-162, 6-13.

Yurtsever, A. V. (1967). Esir Türk İlleri Kurtuluş davasının bugünkü durumu. Azerbaycan, 1798-179-180, 2-7.

Yurtsever, A.V. (1972). "Mehmet Sadık ARAN (SAN'AN). Azerbaycan, 205, 63-66.

Yurtsever, A.V. (1972). Ejder KURTULAN (1898-1971). Azerbaycan, 205, 70-73.

Yurtsever, A.V. (1974). Hüseyin Cemal Yanar'a. Azerbaycan, 210, 71-72.

Yurtsever, A.V. (1974). Molla Penah Vakıf'la İgili Memduh Şevket Esendal İe İgili Bir Hatira. Azerbaycan, 211, 18.

Yurtsever, A. V. (1974). Sovyet Halkı masall. Azerbaycan, 212, 1-6.

Yurtsever, A.V. (1977). Abdulvahap Yurtsever' in vasiyetnamesi. Azerbaycan. 221, 28. 
Yurtsever, A. V. (1991). Gizli Müsavat Teşkilatının karakteristik vasıfları. Azerbaycan, 282. $42-45$.

\section{Kaynakça Bilgisi / Citation Information}

Akın, Ü. (2020). Azerbaycan istiklaline adanmış bir ömür: Abdulvahap Yurtsever. OPUS-Uluslararası Toplum Araştırmaları Dergisi, 16(31), 4559-4587. DOI: 10.26466/opus.691118 